\title{
Quantity component of the effectiveness of seed dispersal by birds in the temperate rainforest of Chiloé, Chile
}

\author{
Componente cuantitativo de la efectividad de dispersión de semillas por aves en el bosque \\ templado de Chiloé, Chile
}

\author{
Miguel Salvande a , Javier A Figueroa ${ }^{\text {b,c,d*, Juan J Armesto }}{ }^{\text {c,e }}$ \\ a Universidade de Santiago de Compostela, Facultade de Bioloxía, Departamento de Ecoloxía e Bioloxía Celular, \\ Área de Ecoloxía, 15782 Santiago de Compostela, España. \\ *Corresponding author: ${ }^{\text {b }}$ Pontificia Universidad Católica de Valparaíso, Facultad de Ciencias, Instituto de Biología, Laboratorio de \\ Ecología Vegetal, Avenida Universidad 330, Curauma, Placilla, Valparaíso, Chile, tel. 5632 2274843, javier.figueroa@ucv.cl \\ 'Pontificia Universidad Católica de Chile, Facultad de Ciencias Biológicas, Center for Advances Studies en Ecology and \\ Biodiversity, Departamento de Ecología, Santiago, Chile. \\ ${ }^{d}$ Universidad Central de Chile, Facultad de Arquitectura, Urbanismo y Paisaje, Escuela de Arquitectura del Paisaje, Santiago, Chile. \\ e Universidad de Chile, Instituto Milenio de Ecología y Biodiversidad (IEB), Santiago, Chile.
}

\begin{abstract}
SUMMARY
The quantity component of the disperser effectiveness of resident birds during the autumn-winter period has not yet been detailed in temperate rainforests of South America. In this study, the potentially frugivorous bird species in the temperate rainforests of southern Chile during the Austral autumn-winter were identified, and the quantity component of the disperser effectiveness of the birds (number of visits and number of seeds dispersed per hour) were evaluated for the tree species Luma apiculata and Aextoxicon punctatum. During the peak fruiting period of the both L. apiculata and A. punctatum 10 and 14, respectively, individuals of each species were monitored for a total of 10 days. Results show that four bird species consumed L. apiculata fruits. The birds Turdus falcklandii were the main fruit consumers ( $72 \%$ of the visits), with a mean rate of 2.2 visits per hour and 49.2 seeds dispersed per hour. The frugivorous species visiting A. punctatum were T. falcklandii (97\% of the visits) and Columba araucana (3\%). In A. punctatum, T. falcklandii consumed 65 fruits in 35 visits, with a mean rate of 1.8 visits per hour and 3.4 seeds dispersed per hour. In conclusion, T. falcklandii would be the most effective seed disperser bird for autumn-winter fruiting trees in the Chiloé rainforest of our study site, at least with regard to the quantitative component of disperser effectiveness.
\end{abstract}

Key words: seed disperser, frugivorous bird, endozoochory, fleshy fruit, South America rainforest.

\section{RESUMEN}

El componente cuantitativo de la efectividad de la dispersión de semillas en aves residentes en los bosques lluviosos de Sudamérica durante el período de otoño e invierno no ha sido descrito con detalle. En este estudio se identificaron las potenciales especies de aves frugívoras de los bosques templados del sur de Chile durante el otoño austral y se evaluó el componente cuantitativo de la efectividad de las aves como dispersantes de semillas (número de visitas y número de semillas dispersadas por hora) en las especies arbóreas Luma apiculata y Aextoxicon punctatum. Durante el periodo de máxima fructificación de los árboles L. apiculata y A. punctatum fueron monitoreados 10 y 14 individuos, respectivamente, por un período de 10 días. Los resultados mostraron que cuatro especies de aves consumieron los frutos de L. apiculata. El ave Turdus falcklandii fue el principal consumidor de frutos ( $72 \%$ de las visitas), con una tasa de 2,2 visitas por hora y 49,2 semillas dispersadas por hora. Los frugívoros que visitaron A. punctatum fueron T. falcklandii (97\% de las visitas) y Columba araucana (3\%). Aquí, T. falcklandii consumió 65 frutos en 35 visitas, con una tasa de 1,8 visitas por hora y 3,4 semillas dispersadas por hora. Se concluye que $T$. falcklandii sería la más efectiva ave dispersante de semillas de los árboles que fructifican en otoño e invierno en los bosques templados del sur de Chile, al menos con respecto al componente cuantitativo de la efectividad del dispersante.

Palabras clave: dispersante de semillas, ave frugívora, endozoocoría, fruto carnoso, bosque lluvioso de Sud América.

\section{INTRODUCTION}

Approximately $70 \%$ of the woody plant species in the temperate rainforests of Chiloé Archipelago, in southern Chile, produce fleshy fruits (Armesto and Rozzi 1989).
This frequency is greater than those recorded for the temperate forests of North America and is comparable to that found in Neotropical forests (Howe and Smallwood 1982, Willson et al. 1996a, Aizen and Ezcurra 1998). Birds are the main fruit consumers in Chiloé; up to $90 \%$ of all 
bird species on the island include fleshy fruits in their diet to some extent (Sabag 1993), mammals and lizards are also important frugivores (Armesto et al. 1987, Willson et al. 1996b, Aizen et al. 2002, Amico et al. 2009). Additionally, investigations into seed germination show that birds in Chiloé act as legitimate seed dispersers, scattering viable propagules (Figueroa and Castro 2002). There is evidence that shows that frugivorous bird assemblages in the Chiloé Archipelago had important consequences on the post-glacial colonization (Villagrán et al. 1986), forest structure and succession (Hernández 1995, Garcia et al. 2010), germination traits (Figueroa 2003), seed dormancy (Figueroa and Armesto 2001), and are actively associated to flowering and fruiting patterns (Smith-Ramírez and Armesto 1994, Smith-Ramírez et al. 1998).

Most woody plant species in Chiloé produce their fruits during the austral summer, between November and March (Smith-Ramírez and Armesto 1994). During this period, the most abundant frugivorous birds are the migratory species Elaenia albiceps D' Orbigny and Lafresnaye (Tyrannidae). There are previous studies which show that, at least in the temperate rainforests of Chiloé and Argentina, E. albiceps is the most important seed dispersal agent in terms of abundance, distribution, and number of visits to fleshyfruiting plants (Sabag 1993, Hernández 1995, Rozzi et al. 1996, Amico and Aizen 2005). Nevertheless, E. albiceps migrates to the rainforests of Southern Amazonia during the austral autumn (Araya and Millie 1986), and there is little knowledge on fruit consumers and seed dispersers of fleshy fruits produced during the austral autumn and winter, between May and September (Correa et al. 1990, Rozzi et al. 1996). From 44 bird species recorded in the temperate rainforests of Chiloé, only three resident species are considered habitual fleshy-fruit consumers (Rozzi et al. 1996). There are reports that show that the resident species Turdus falcklandii Quoy and Gaimard (Turdinae) may be important frugivores in the secondary rainforests of Chiloé (Willson et al. 1996a) and the Coastal Range (Díaz 2005). Also mentioned as frugivores, but to a lesser extent, are Curaeus curaeus (Molina) (Icterinae), Columba araucana Lesson (Columbidae) and Scelorchilus rubecula Kittlitz (Rhinocryptidae) (Correa et al. 1990, Rozzi et al. 1996). However, disperser effectiveness (sensu Schupp 1993) of resident birds during the austral autumn-winter period has not yet been detailed. Disperser effectiveness is the number of new adult plants produced as a result of the activity of one disperser relative to the other dispersers or to nondispersed seeds (Schupp 1993, Calviño-Cancela and Martín-Herrero 2009). The effectiveness of seed dispersers depends both on the interaction event frequency and on the net effect per event (quantity and quality of dispersal sensu, Schupp 1993). However, studies in the rainforests of Chiloé on disperser effectiveness during the austral autumn-winter are scarce (Hernández 1995, Figueroa and Castro 2002) despite the importance of these concepts for seed dispersal ecology (Schupp 1993, Godinez-Alvarez et al. 2002, Calviño-Cancela and Martín-Herrero 2009). It is hypothesized that during the austral autumn-winter the guild of seed disperser birds is depleted.

Although effectiveness remains largely uninvestigated due to the complexity of its measurement, we aimed to determine the quantitative components of disperser effectiveness for the trees Aextoxicon punctatum R. et P. (Aextoxicaceae) and Luma apiculata (DC.) Burret (Myrtaceae). In Chiloé, both tree species have their maximum fruit crop during the austral autumn and winter (Smith-Ramírez and Armesto 1994).

The main objectives of this investigation are: (1) To identify the potentially frugivorous bird species of two autumnal fruiting trees in the Chiloé rainforest (Aextoxicon punctatum and Luma apiculata) and the abundance of these birds; (2) to determine the quantitative components of disperser effectiveness of the frugivorous birds in both tree species (number of visits and number of seeds dispersed per hour).

\section{METHODS}

Study area and species. The study area was located in the

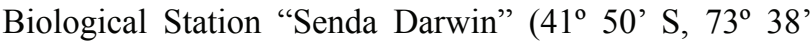
W), $18 \mathrm{~km}$ north-east of Ancud, in Isla Grande, Chiloé, Chile. The landscape is slightly uneven with low slopes and altitudes between 0 and 100 meters above sea level. Soils are thin, of glacial origin and are frequently not well drained. The weather in Northern Chiloé is rainy (annual mean of 2,100 $\mathrm{mm}$ ) with a strong oceanic influence, which contributes to mild temperatures, with a maximum mean of $16{ }^{\circ} \mathrm{C}$ (January) and minimum mean temperatures of $5{ }^{\circ} \mathrm{C}$ (July), approximately. The typical vegetation in the area is comprised by a mosaic of antropogenic prairies and patches of primary and successional forests. Primary forests are mainly dominated by Nothofagus nitida (Phil) Krasser (Fagaceae), Drimys winteri J. R. et G. Forster (Winteraceae), Podocarpus nubigena Lindl (Podocarpaceae) and several species of Myrtaceae of the genera Amomyrtus and Myrceugenia. Successional areas are dominated by shrubs such as Baccharis spp., Berberis spp., and several species of isolated trees, mainly Drimys winteri, Embothrium coccineum and Luma apiculata. To achieve the objectives of the research, we selected the trees Luma apiculata and Aextoxicon punctatum (table 1) because they produce an abundant crop of fleshy fruits, whereas the production of other tree species is low and sporadic during austral autumn and winter in the study sites.

The two tree species were not selected in the same sites as they do not share habitat. Mainly, L. apiculata individuals were selected on the edges of secondary woody vegetation patches, close to water courses where the species is abundant in Biological Station "Senda Darwin". On the other hand, A. punctatum trees were selected only in a small patch of remnant forest close to the city of 
Table 1. The two tree species studied in the temperate rainforest of southern Chile. Their taxonomic assignment, life form, forest habitat, flowering period, fruiting period and fruit and seed characteristics are indicated.

Dos especies de árboles estudiados en el bosque del sur de Chile. Se indica su filiación taxonómica, forma de vida, hábitat del bosque, periodo de floración, período de fructificación y características de los frutos y semillas.

\begin{tabular}{lcc}
\hline Characteristics & $\begin{array}{c}\text { Luma } \\
\text { apiculata }\end{array}$ & $\begin{array}{c}\text { Aextoxicon } \\
\text { punctatum }\end{array}$ \\
\hline Family & Myrtaceae & Aextoxicaceae \\
Life form & Tree & Tree \\
Forest habitat & Edge & Interior \\
Flowering period & Autumn & Summer \\
Fruiting period & Winter & Autumn \\
Fruit type & Berry & Drupe \\
Fruit color & Black & Black \\
Fruit mass (mg) & 300 & 300 \\
Seed mass (mg) & 10 & 260 \\
Seed per fruit & $4-7$ & 1 \\
\hline
\end{tabular}

Ancud (Quempillén). This patch was located at less than $50 \mathrm{~m}$ from the coastline, adjacent to highway Ruta 5 and close to the Northern of Puente Pudeto ( $41^{\circ} 53^{\prime} \mathrm{S}$; $73^{\circ} 50^{\prime}$ W). This A. punctatum fragment has an estimated area of 18 ha, and is the only patch $>10$ ha in the study area. The edges of the patch have recently been colonized by exotic shrubs, particularly Ulex europaeus L. (Papilionaceae) and Cytisus scoparius L. (Papilionaceae).

Identification and abundance of birds. Potentially frugivorous birds were recorded and identified by direct observation with binoculars along a $2 \mathrm{~km}$ long transect, running through the riparian vegetation of Biological Station "Senda Darwin", which presented L. apiculata adult established inside the remnant forest of $A$. punctatum ("olivillo"). Over 10 days, transects were repeated between April and May. Transects were performed by walking very slowly and stopping irregularly in order to observe and identify the potentially frugivorous birds. Each transect was performed over a period of at least three hours, approximately.

We considered a bird species as potentially frugivores when its mouth gape was at least as large as the mean fruit diameter of L. apiculata and A. punctatum (Armesto et al. 1987). In this study, there were no narrow mouthed birds consuming fruits, although they may eventually be seed dispersers (see Armesto et al. 1987, Correa et al. 1990, Rozzi et al. 1996, and Díaz 2005 for more details on frugivorous bird species). There are other potentially frugivorous vertebrates identified in secondary forests of Chiloé, for example the marsupial Dromiciops gliroides (Microbiotheria: Microbiotheriidae) (Amico et al. 2009), which will not be studied in this opportunity.
Quantitative component of disperser effectiveness. Fruit consumption by birds was observed during visits to 10 isolated trees of $L$. apiculata with abundant fruit crops in an area of $2 \mathrm{~km}^{2}$ in "Senda Darwin". The order of the field observations of the trees was always the same. Consumption on L. apiculata was recorded over 13 consecutive days in May and the observations were performed between 08:00 and 16:00 $\mathrm{h}$, with a total of 24 hours.

To record fruit consumption on $14 \mathrm{~A}$. punctatum trees, over 10 days between April and May, direct observations were performed. During this period, A. punctatum trees present their maximum crop of ripe fruits. Completing a total of 20 hours on A. punctatum, observations were made on clear days between 08:00 and 10:00 h, when birds have their highest activity levels in Chiloé (Sabag 1993).

In both tree species, we recorded the number of birds visiting each $L$. apiculata and A. punctatum trees per hour, and the number of fruits ingested per hour. To estimate how seeds are dispersed per hour, the number of birds visiting per hour was multiplied by the number of fruits ingested per visit. To obtain the number of $L$. apiculata seeds dispersed per hour it was considered that each fruit contained four seeds (table 1). The A. punctatum fruits contain one seed.

We assumed that the frugivorous birds are legitimate seed dispersers during austral winter because there is indirect evidence to indicate this (Correa et al. 1990, Hernández 1995, Willson et al. 1996c, Figueroa and Castro 2002). Specifically, studies in L. apiculata have demonstrated that seeds are not digested by frugivorous birds, and its seeds require that the fruit pulp be digested previously in order to germinate (Figueroa and Castro 2001). Evidence also shows that A. punctatum seeds are not digested and germination is not ceased by frugivorous birds: seeds obtained from fruits germinated to the same extent as those seeds ingested by birds ${ }^{1}$.

\section{RESULTS}

Identification and abundance of birds. Four bird species were recorded as potential L. apiculata fruit consumers (table 2). Turdus falcklandii was significantly the most abundant (118 individuals), followed by Phytotoma rara Molina (Phytotomidae), Colaptes pitius Molina (Picidae) and Curaeus curaeus Molina with 26, 5, and 2 individuals, respectively $\left(\chi^{2}=99.1 ; P<0.001\right)$. The frugivores found in the "olivillo" forest patch were T. falcklandii $(1,760$ individuals) and C. araucana (300 individuals) (table 2). Here, T. falcklandii was significantly more abundant than C. araucana $\left(\chi^{2}=590.1 ; P<0.001\right)$.

Quantitative component of disperser effectiveness. Turdus falcklandii was the main potential frugivore visiting L. apiculata trees, constituting $72 \%$ of the feeding visits recorded $(\mathrm{n}=53)$ at a rate of 2.2 feeding visits per hour

\footnotetext{
${ }^{1}$ M Salvande: data not published.
} 
Table 2. Identification and abundance of potentially frugivorous birds in the secondary forests and "olivillo" forests of Chiloé, Chile. Birds were recorded between April and May (Austral autumn). Mean of observations \pm 1 S.D. is indicated.

Identificación y abundancia de aves potencialmente frugívoras en bosque secundarios y bosques de "olivillo" de Chiloé. Las aves fueron registradas entre abril y mayo (otoño austral). Se indica la media de las observaciones \pm 1 D.E.

\begin{tabular}{|c|c|c|c|c|}
\hline Forest type & Birds & $\begin{array}{l}\text { Abundance (number } \\
\text { of individuals) }\end{array}$ & Percentage & $\begin{array}{l}\text { Birds observed } \\
\text { per hour }\end{array}$ \\
\hline \multirow[t]{4}{*}{ Secondary forest } & Turdus falcklandii & 118 & 78 & $4.9 \pm 4.9$ \\
\hline & Phytotoma rara & 26 & 17 & $1.1 \pm 1.6$ \\
\hline & Colaptes pitius & 5 & 4 & $0.2 \pm 0.6$ \\
\hline & Curaeus curaeus & 2 & 1 & $0.1 \pm 0.4$ \\
\hline \multirow[t]{2}{*}{ "Olivillo" forest } & Turdus falcklandii & 1,760 & 85 & $88 \pm 62$ \\
\hline & Columba araucana & 300 & 15 & $15 \pm 22$ \\
\hline
\end{tabular}

(table 3). Phytotoma rara constituted $24 \%$ of the feeding visits $(\mathrm{n}=18)$, with a rate of nearly one feeding visit per hour. Colaptes pitius and C. curaeus were occasional L. apiculata fruit consumers, with $<0.1$ feeding visit per hour (table 3). Rate of feeding visits of T. falcklandii was significantly higher than that of the other birds $\left(\chi^{2}=44.1\right.$; $P<0.001)$.

In L. apiculata, T. falcklandii consumed about $73 \%$ of the total number of ingested fruits, with a mean rate of 5.6 fruits ingested per visit. Phytotoma rara presented a similar mean rate of 5.4 fruits ingested per visit (table 3 ). Colaptes pitius presented rates significantly lower of three fruits per visit, and six fruits were consumed in the only feeding visit observed for $C$. curaeus $\left(\chi^{2}=89.1 ; P<0.001\right)$.

For $A$. punctatum trees, we recorded a total of 37 feeding visits, $97 \%$ of them $(\mathrm{n}=36)$ by Turdus falcklandii individuals, and only one visit by $C$. araucana. We observed 1.8 feeding visits per hour by $T$. falcklandii, whereas C. araucana carried out only 0.05 feeding visits per hour (table 2). Turdus falcklandii individuals were observed consuming $65 \mathrm{~A}$. punctatum fruits in 35 feeding visits, which corresponds to 1.9 fruits ingested per visit.
For the only C. araucana feeding visit, we recorded a consumption of eight fruits (table 3 ).

For the quantitative component of disperser effectiveness, in this study $T$. falcklandii presented the greatest effectiveness for both plants. The bird species T. falcklandii dispersed 49.2 seeds per hour for L. apiculata and 3.4 seeds per hour for A. punctatum. Phytotoma rara dispersed 17.2 L. apiculata seeds per hour. Colaptes Pitius and C. curaeus presented the significantly lowest effectiveness for L. apiculata $\left(\chi^{2}=1106 ; P<0.001\right)$, and $C$. araucana had the significantly lowest effectiveness for A. punctatum $\left(\chi^{2}=34.7 ; P<0.001\right)$ (table 3$)$.

\section{DISCUSSION}

The main frugivorous birds observed during the summer months in the temperate rainforests of southern Chile are the migratory E. albiceps and the resident T. falcklandii (Sabag 1993, Hernández 1995). This study shows that during Austral autumn-winter T. falcklandii becomes the most important frugivore. Turdus falcklandii was the most abundant bird species throughout the study

Table 3. Quantitative components of disperser effectiveness during autumn and winter in Chiloé forests. Number of bird visits per hour, number of fruits ingested per bird visit, and number of seeds dispersed per hour. Mean of observations \pm 1 S.D. is indicated. * Denotes observation of one single individual.

Componentes cuantitativos de la efectividad de los dispersantes durante el otoño e invierno en los bosques de Chiloé. Número de visitas de aves por hora, número de frutos ingeridos por visita de aves y número de semillas dispersadas por hora. Se indica la media de las observaciones \pm 1 D.E. *Señala la observación de un solo individuo.

\begin{tabular}{llcccc}
\hline \multicolumn{1}{c}{ Tree species } & Frugivorous bird & $\begin{array}{c}\text { Hours of } \\
\text { observation }\end{array}$ & $\begin{array}{c}\text { Bird visits } \\
\text { per hour }\end{array}$ & $\begin{array}{c}\text { Fruits ingested } \\
\text { per visit }\end{array}$ & $\begin{array}{c}\text { Seed dispersed } \\
\text { per hour }\end{array}$ \\
\hline & Turdus falcklandii & & $2.2 \pm 1.7$ & $5.6 \pm 3.6$ & $49.2 \pm 21.2$ \\
& Phytotoma rara & 24 & $0.8 \pm 1.0$ & $5.4 \pm 2.9$ & $17.2 \pm 15.6$ \\
Luma apiculata & Colaptes pitius & & $0.08 \pm 0.3$ & $3.0 \pm 0$ & $1.0 \pm 1.2$ \\
& Curaeus curaeus* & & 0.04 & 6 & 0.24 \\
\hline $\begin{array}{l}\text { Aextoxicon } \\
\text { punctatum }\end{array}$ & Turdus falcklandii & \multirow{2}{*}{20} & $1.8 \pm 2.3$ & $1.9 \pm 1.2$ & $3.4 \pm 3.5$ \\
\hline
\end{tabular}


period, as has been recorded in other different temperate rainforests in southern Chile during autumn and winter months (Sabag 1993, Hernández 1995).

Although this study does not prove that T. falcklandii is a legitimatedisperser for the treespecies studied, theevidence ${ }^{2}$ sustains that this species may well be a disperser of viable seeds of both L. apiculata and A. punctatum (Figueroa and Castro 2003). Seed germination of both L. apiculata and A. punctatum obtained from bird feces collected at random in the field, during the autumn, is similar to the seed germination obtained in fruits recently collected on the mother plants (Figueroa and Castro 2003). According to our results of bird abundance, there is a high probability that the feces collected at random in the field during autumn belong to $T$. falcklandii. However, the hypothesis should be corroborated in later studies.

These results confirm that temperate rainforests of South America have low diversity of frugivorous birds (Sabag 1993, Hernández 1995, Amico and Aizen 2005), which contrasts with the observations carried out in other temperate regions around the world (Stepanian 1982, Debussche and Isenman 1989, Stanley and Lill 2002, Jordano et al. 2007). This is most likely due to their isolation from other South America forests since the Pliocene (Hinojosa and Villagrán 1997).

Specifically, the "olivillo" forest studied has the lowest diversity of frugivorous birds. Nearly all of the feeding visits on A. punctatum trees were of T. falcklandii and $<5 \%$ were $C$. araucana. In addition, $T$. falcklandii is also the main visitor of $L$. apiculata, with $65 \%$ of feeding visits. Nevertheless, other three bird species are responsible for the remaining $L$. apiculata fruit consumption.

In the study period, $T$. falcklandii was sighted 18 times more frequently in the "olivillo" patch than in the secondary forest where L. apiculata was common. However, T. falcklandii has similar rates of feeding visits to both tree species (2.2 and 1.8 bird visits per hours in L. apiculata and $A$. punctatum, respectively). Regarding the dispersed seeds per hour (the quantitative component of effectiveness), in this study T. falcklandii was less effective on A. punctatum fruit (3.4 seeds per hours) than when feeding on L. apiculata fruit (49.2 seeds per hours). Also, in this last tree, the quantity of seeds dispersed per hour was significantly greater for $T$. falcklandii, indicating probably higher effectiveness of the quantitative component due to greater abundance in the study site and more seeds per fruit. The remaining bird species dispersed $<30 \%$ of the L. apiculata seeds. This greater abundance of T. falcklandii, recorded during the study period in Chiloé, may show that the number of visits a disperser makes appears to be a better predictor of the total quantity of seed dispersed than the number of fruits ingested per visit (Schupp 1993).

In addition, a study ${ }^{3}$ directly done on the "olivillo" understory shows that $>90 \%$ of the $A$. punctatum propagules

\footnotetext{
${ }^{2}$ M Salvande: data not published.

${ }^{3}$ M Salvande: data not published.
}

were intact in the site and would mean that propagules fall from trees without being consumed by frugivores and/or that animals handle them in a deficient way (Snow and Snow 1988). Studies in different communities also have shown crops that are ignored by endozoochorous dispersers (Snow and Snow 1988, Fuentes 2000). In our study, the proportion of $A$. punctatum fruits dispersed by birds, as well as the number of fruits ingested per visit, is very low when compared to data found for L. apiculata and other woody species (Stanley and Lill 2002, Obeso and Fernández-Calvo 2002). Our results seem to suggest that fruit size would be a limiting factor for birds foraging on A. punctatum fruits. L. apiculata fruits are smaller in size than those of A. punctatum (table 1). Therefore, in the temperate rainforests of southern Chile, $L$. apiculata could be a less discriminatory source of ripe fruits than $A$. punctatum, because the bird species present in the region generally have beak gapes smaller than $A$. punctatum fruit diameter (Armesto et al. 1987). This may also explain why the lowest diversity of frugivorous birds is found in the patch dominated by A. punctatum and the low effectiveness of T. falcklandii on A. punctatum fruits, at least with regard to the quantitative components of disperser effectiveness. In addition, the relative amount of pulp per fruit is lower in A. punctatum than in L. apiculata. However, we do not have data regarding nutrient content relative to the pulp for both species, which are important variables when considering fruits as food resources for frugivores (Jordano 1995).

In conclusion, in the study site we observed four frugivorous birds during autumn-winter (T. falcklandii, P. rara, C. pitius and C. curaeus). Similarly, there is evidence that $T$. falcklandii is an important seed disperser during autumn-winter in the temperate forests of South America (Amico and Aizen 2005). Regarding quantity component of disperser effectiveness, this study shows that $T$. falcklandii would be the most effective disperser bird in the rainforests of Chiloé. First, fleshy fruits produced during austral autumn and winter were principally ingested and the seeds probably dispersed by $T$. falcklandii. Secondly, P. rara, which consumes a great number of L. apiculata fruits per visit, is present in lower abundance and disperses a lower number of seeds during this period. Finally, as the measurements were obtained on quantitative components of disperser effectiveness and only in one study site by tree species, additional investigation is recommended to extend the research over qualitative components of effectiveness, and over the spatial and interannual variation of the Chiloé forests.

\section{ACKNOWLEDGEMENTS}

During his stay in Chile, M Salvande was supported by a pre-doctoral degree granted by the Spanish Ministry of Science and Education (AP97-33299901), and he wishes to thank all the staff in "Senda Darwin" for their warm assistance during his staying in Chiloé. JA Figueroa was 
supported by Vice-Rectoría de Investigación y Estudios Avanzados, Pontificia Universidad Católica de Valparaíso. We would like to thank three anonymous reviewers who commented on this manuscript.

This is contribution to the research program of Senda Darwin Biological Station, Chiloé.

\section{REFERENCES}

Aizen MA, C Ezcurra. 1998. High incidence of plant-animal mutualisms in the woody flora of the temperate forest of South America: biogeographical origin and present ecological significance. Ecología Austral 8: 217-236.

Aizen MA, DP Vázquez, C. Smith-Ramírez. 2002. Historia natural y conservación de los mutualismos planta-animal del bosque templado de Sudamérica austral. Revista Chilena de Historia Natural 75: 79-97.

Amico GC, MA Aizen. 2005. Dispersión de semillas por aves en un bosque templado de Sudamérica austral: ¿quién dispersa a quién? Ecología Austral 15: 89-100.

Amico GC, M Rodríguez-Cabal, MA Aizen. 2009. The potential key seed-dispersing role of the arboreal marsupial Dromiciops gliroides. Acta Oecologica 35: 8-13.

Araya B, G Millie. 1986. Guía de campo de las aves de Chile. Santiago, Chile. Editorial Universitaria. 405 p.

Armesto JJ, R Rozzi. 1989. Seed dispersal syndromes in the rain forest of Chiloé: evidence for the importance of biotic dispersal in a temperate rain forest. Journal of Biogeography 16: 219-226.

Armesto JJ, R Rozzi, P Miranda, C Sabag. 1987. Plant/frugivore interactions in South American temperate forest. Revista Chilena de Historia Natural 60: 321-336.

Calviño-Cancela M, J Martin-Herrero. 2009. Effectiveness of a varied assemblage of seed dispersers of a fleshy-fruited plant. Ecology 90: 3503-3515.

Correa A, JJ Armesto, RP Schlatter, R Rozzi, JC Torrez-Mura. 1990. La dieta del chucao (Scelorchilus rubecula), un Passeriforme terrícola endémico del bosque templado húmedo de Sudamérica Austral. Revista Chilena de Historia Natural 63: 197-202.

Debussche M, P Isenman. 1989. Fleshy fruit characters and choices of bird and mammal seed dispersers in a Mediterranean region. Oikos 56: 327-338.

Díaz IA. 2005. Historia natural, diversidad y conservación de las aves en bosques de la Cordillera de la Costa de la región de Los Lagos. In Smith-Ramírez C, JJ Armesto, C Valdovinos eds. Historia, biodiversidad y ecología de los bosques costeros de Chile. Santiago, Chile. Editorial Universitaria. p. 456-466.

Figueroa JA. 2003. Seed germination in temperate rain forest species of southern Chile: chilling and gap-dependant germination. Plant Ecology 166: 227-240.

Figueroa JA, JJ Armesto. 2001. Community-wide germination strategies in a temperate rainforest of Southern Chile: ecological and evolutionary correlates. Australian Journal of Botany 49: 1-15.

Figueroa JA, SA Castro. 2002. Effect of bird ingestion on seed germination of four woody species of the temperate rainforest of the Chiloé island, Chile. Plant Ecology 160: 17-23.

Fuentes M. 2000. Frugivory, seed dispersal and plant community ecology. Tree 15: 487 -488.

Garcia D, R Zamora, GC Amico. 2010. Birds as suppliers of seed dispersal in temperate ecosystems: conservation guidelines from real-world landscapes. Conservation Biology 24: 1070-1079.

Godinez-Alvarez H, A Valiente-Banuet, A Rojas-Martinez. 2002. The role of seed dispersers in the population dynamics of the columnar cactus Neobuxbaumia tetetzo. Ecology 83: 2617-2629.

Hernández JF. 1995. Efecto de los árboles percha sobre los patrones de la lluvia de semillas y el establecimiento de plántulas: consecuencias para la sucesión secundaria del bosque de Chiloé. Tesis Doctorado en Ciencias. Santiago, Chile. Facultad de Ciencias, Universidad de Chile. 83 p.

Hinojosa LF, C Villagrán. 1997. Historia de los bosques del sur de Sudamérica, I: antecedentes paleobotánicos, geológicos y climáticos del Terciario del cono sur de América. Revista Chilena de Historia Natural 70: 225-239.

Howe HF, J Smallwood. 1982. Ecology of seed dispersal. Annual Review of Ecology and Systematics 13: 201-228.

Jordano P. 1995. Angiosperm fleshy fruits and seed dispersers: a comparative analysis of adaptation and constraints in plantanimal interactions. American Naturalist 145: 163-191.

Jordano P. C García, JA Godoy, JL García-Castellano. 2007. Differential contribution of frugivores to complex seed dispersal patterns. Proceeding of the Nacional Academy of Sciences 104: 3278-3282.

Obeso JR, IC Fernández-Calvo. 2002. Fruit removal, pyrene dispersal, post-dispersal predation and seedling establishment of a bird-dispersed tree. Plant Ecology 165: 223-233.

Rozzi R, D Martínez, MF Willson, C Sabag. 1996. Avifauna de los bosques templados de Sudamérica. In Armesto JJ, C Villagrán, MTK Arroyo eds. Ecología de los Bosques Nativos de Chile. Santiago, Chile. Editorial Universitaria. p. $135-152$.

Sabag C. 1993. El rol de las aves en la dispersión en la dispersión de semillas en el bosque templado secundario de Chiloé $\left(42^{\circ} \mathrm{S}\right)$. Tesis de Magíster en Ciencias. Santiago, Chile. Facultad de Ciencias, Universidad de Chile. 78 p.

Schupp EW. 1993. Quantity, quality and the effectiveness of seed dispersal by animals. Vegetatio 107/108: 15-29.

Snow B, D Snow. 1988. Birds and Berries. Staffordshire, London. T \& AD Poyser. 268 p.

Smith-Ramírez C, JJ Armesto. 1994. Flowering and fruiting patterns in the temperate rainforest of Chiloé, Chile: ecologies and climatic constraints. Journal of Ecology 82: 353-65.

Smith-Ramírez C, JJ Armesto, J Figueroa. 1998. Flowering, fruiting and seed germination in Chilean rain forest Myrtaceae: ecological and phylogenetic constraints. Plant Ecology 136: 119-131.

Stanley MC, A Lill. 2002. Avian fruit consumption and seed dispersal in a temperate Australian woodland. Austral Ecology 27: 137-148.

Stepanian MA. 1982. Evolution of fruiting strategies among fleshy-fruited plant species of eastern Kansas. Ecology 63: 1422-1431.

Villagrán C, JJ Armesto, R Leiva. 1986. Recolonización postglacial de Chiloé insular: evidencias basadas en la distribución geográfica y los modos de dispersión de la flora. Revista Chilena de Historia Natural 59: 19-39.

Willson MF, TL de Santos, C Sabag, JJ Armesto. 1996a. Avian 
communities in temperate rainforest of North and South America. In Lawford RG, P Alaback, ER Fuentes eds. Hight Latitude Rain Forest and Associated Ecosystems of the West Coast of the Americas: Climate, Hydrology, Ecology and Conservation. New York, Springer-Verlag. p. 228-247.
Willson MF, C Sabag, J Figueroa, JJ Armesto, M Caviedes. 1996b. Seed dispersal by lizards in Chilean rainforest. Revista Chilena de Historia Natural. 69: 339-342.

Willson MF, C Sabag, J Figueroa, JJ Armesto. 1996c. Frugivory and seed dispersal of Podocarpus nubigena in Chiloé. Revista Chilena de Historia Natural 69: 343-349.

Recibido: 03.08.10

Aceptado: 09.12.10 